\title{
PERANCANGAN SISTEM INFORMASI PERSEDIAAN BAHAN BAKU DI UD. XY, TULUNGAGUNG
}

\section{DESIGN OF RAW MATERIAL INVENTORY INFORMATION SYSTEM AT UD. XY, TULUNGAGUNG}

Retno Astuti, Reza Ashari, dan Mas'ud Effendi

\author{
Jurusan Teknologi Industri Pertanian, Fakultas Teknologi Pertanian,Universitas Brawijaya \\ Jl. Veteran-Malang, Indonesia \\ Email: retno_astuti@ub.ac.id
}

Makalah: Diterima 12 November 2018; Diperbaiki 22 Juni 2019; Disetujui 10 Juli 2019

\begin{abstract}
The availability of raw material supplies is very important in maintaining the sustainability of the production process in a company. The purpose of this research was to design a web-based raw material inventory information system to meet the needs of users in controlling shanghai peanut raw material supplies. The system approach method used in this study was prototyping. System design used the concept of Object Oriented Programming (OOP) with UML version 2.0, MySQL and XAMPP databases as local servers and the PHP programming language. The result of the information were information about the list of raw materials, supply of raw materials, use of raw materials, and availability of raw materials for shanghai peanut in the warehouse. Verification and validation tests using the black box method and the system design test showed that the results of the information system design have been running well and as expected
\end{abstract}

Keywords: information system, inventory, peanut,raw materials

\section{ABSTRAK}

Ketersediaan pasokan bahan baku merupakan hal yang sangat penting dalam menjaga keberlangsungan proses produksi di suatu perusahaan. Tujuan penelitian ini adalah merancang sistem informasi persediaan bahan baku berbasis web untuk memenuhi kebutuhan pengguna dalam pengendalian persediaan bahan baku kacang shanghai. Metode pendekatan sistem yang digunakan dalam penelitian ini adalah prototyping. Perancangan sistem menggunakan konsep Object Oriented Programming (OOP) dengan $U M L$ versi 2.0, database MySQL dan $X A M P P$ sebagai local server serta bahasa pemrograman PHP. Informasi yang dihasilkan adalah informasi mengenai daftar bahan baku, pasokan bahan baku, penggunaan bahan baku, serta ketersediaan bahan baku kacang shanghai dalam gudang. Uji verifikasi dan validasi menggunakan metode black box serta uji rancangan sistem menunjukkan bahwa hasil rancangan sistem informasi telah berjalan dengan baik dan sesuai yang diharapkan.

Kata kunci: bahan baku, kacang, persediaan, sistem informasi

\section{PENDAHULUAN}

Sebuah perusahaan dalam upaya memenuhi kebutuhan informasi memerlukan pengolahan data yang sistematis, yaitu dengan cara membentuk suatu sistem informasi. Penerapan sistem informasi perlu ditunjang dengan teknologi informasi, yaitu pemanfaatan komputer beserta aplikasinya dan penggunaan jaringan komputer sebagai media untuk mendistribusikan data dan informasi. Salah satu penerapan sistem informasi pada perusahaan adalah sistem informasi untuk persediaan bahan baku.

Perusahaan UD. XY merupakan perusahaan yang bergerak dibidang produksi dan distribusi makanan ringan yang didirikan pada tahun 1981 di Kecamatan Ngunut, Tulungagung, Jawa Timur dengan meluncurkan merk Kacang Shanghai Gangsar. Bahan baku utama yang diperlukan dalam membuat kacang shanghai terdiri dari bahan baku utama kacang tanah jenis High Class (HC) yang berukuran $7 \mathrm{~mm}$ serta tepung yang terdiri dari tepung terigu dan tapioka. Bahan baku pendukung produksi kacang shanghai adalah bawang putih, garam, gula, penyedap rasa, telur, minyak goreng, dan air. Produksi kacang shanghai mengalami peningkatan dari tahun 2014 dengan total produksi mencapai $2988741 \mathrm{~kg}$ hingga total produksi mencapai $2800437 \mathrm{~kg}$ dari bulan Januari sampai Oktober pada tahun 2016. Peningkatan produksi kacang shanghai tersebut memerlukan ketersediaan bahan baku yang dapat mendukung proses produksi secara berkelanjutan. Oleh karena itu, pengendalian bahan baku kacang shanghai sangat perlu dilakukan di UD. XY.

Sistem informasi persediaan barang di gudang UD. XY pada saat ini masih kurang efektif. Hal ini dikarenakan proses pencatatan barang masih dilakukan secara manual dengan mencatat ketersediaan barang kemudian catatan diserahkan ke 
bagian administrasi untuk dilakukan dokumentasi. Kondisi tersebut mengakibatkan proses penyebaran informasi dari pihak gudang ke bagian kantor terhambat. Proses aliran sistem informasi yang tidak lancar dapat menyebabkan proses pengambilan keputusan terhambat sehingga perusahaan kehilangan kesempatan untuk meraih keuntungan. Masalah ini dapat diatasi dengan pengembangan sistem informasi persediaan yang terkomputerisasi. Menurut Alter (2008), sistem informasi adalah sistem dengan komponen manusia dan mesin yang melakukan pekerjaan (proses dan kegiatan) menggunakan informasi, teknologi, dan sumber daya lain untuk menghasilkan produk dan / atau layanan informasi bagi pelanggan internal atau eksternal. Hampir semua sektor industri di era Industri 4.0 pada dasarnya bergantung pada penerapan sistem informasi dan teknologi informasi yang efektif. Perkembangan perangkat pintar terhubung dan internet of things' membuka peluang untuk efisiensi operasional. Sistem informasi juga penting dalam persediaan bahan baku. Oleh karena itu, perancangan sistem informasi persediaan bahan baku dilakukan pada penelitian ini.

Penelitian mengenai sistem informasi persediaan telah dilakukan oleh beberapa peneliti. Aristyanto (2013) telah melakukan penelitian tentang perancangan sistem informasi pengendalian intern persediaan barang pada suatu usaha jasa pendidikan. Aplikasi sistem informasi pada perancangan tersebut hanya dipegang oleh satu pengguna, yaitu bagian administrasi gudang, dan masih bersifat offline. Perancangan sistem informasi persediaan barang berbasis web juga sudah pernah dilakukan oleh Ramadhan (2008). Hal tersebut dilakukan pada sebuah perguruan tinggi dalam kegiatan inventarisasi barang yang meliputi pengajuan, pembelian, pencatatan, dan pendistribusiannya untuk keperluan penunjang kegiatan belajar mengajar, keperluan pegawai dalam melaksanakan pekerjaannya melayani mahasiswa dan dosen, serta pelaporannya. Perancangan aplikasi sistem pengendalian persediaan dengan teknologi informasi yang lebih canggih telah dilakukan oleh Ravinchandra et al. (2016). Smartphone android digunakan pada penelitian ini untuk pengendalian persediaan dengan sistem teknologi RadioFrequency Identification (RFID).

Penelitian ini berbeda dengan penelitianpenelitian yang telah dilakukan sebelumnya. Bahan baku utama berupa kacang tanah yang dipertimbangkan dalam penelitian ini merupakan bahan pertanian yang mempunyai karakteristik khusus yang perlu dipertimbangkan dalam persediaannya, antara lain mengalami perubahan secara biologis selama disimpan dan ketersediannya tergantung cuaca. Menurut Cantwell (2014) dan Prusak et al. (2014), masalah keamanan pangan utama untuk kacang tanah adalah aflatoksin yang diproduksi oleh jamur Salmonella $s p$ dan bakteri
Listeria monocytogenesyang menyebabkan penyakit pada manusia. Pertumbuhan jamur dan bakteri tersebut dipengaruhi oleh kadar air dan suhu kacang tanah. Kondisi penyimpanan penting untuk umur simpan kacang tanah. Umur simpan tergantung pada varietas kacang tanah dan dipengaruhi oleh udara, suhu, atau faktor penyebab oksidasi.Waktu maksimum penyimpanan kacang adalah sekitar dua bulanuntuk menghindari masalah dengan aflatoksin.

Sistem informasi dirancang pada penelitian ini berbasis web dan dapat dijalankan secara online sehingga dapat diakses setiap waktu di lokasi yang berbeda oleh beberapa pengguna yang telah terdaftar yang masih berada dalam area Local Area Network $(L A N)$ perusahaan. Tujuan penelitian ini adalah merancang sistem informasi persediaan bahan baku berbasis web untuk memenuhi kebutuhan pengguna dalam pengendalian persediaan bahan baku kacang shanghai.

\section{METODE PENELITIAN}

Perancangan sistem informasi persediaan bahan baku menggunakan perangkat Personal Computer (PC) yang terdiri dari hardware dan software. Hardware yang digunakan adalah komputer dengan spesifikasi Processor Intel Core I3-4005U CPU @1.7 Ghz, MemoryDDR III 4 GB $R A M$, dan Harddisk 500 GB. Software yang digunakan untuk merancang sistem informasi persediaan bahan baku adalah Operating System Windows 10 Pro 64-bit (10.0, Build 14393) serta software pembangun sistem informasi persediaan bahan baku, yaitu Sublime text 2 sebagai text editor basis data, XAMPP 7.1.8 sebagai server localhost, dan MySQL sebagai basis data.

Sistem informasi persediaan bahan bakukacang shanghai pada penelitian ini berfokus pada persediaan bahan baku, jumlah stok bahan baku, serta informasi pengeluaran dan pemasukan bahan baku. Sistem informasi yang digunakan hanya pada bagian gudang bahan baku dan digunakan oleh bagian administrasi gudang, operator/mandor gudang, dan manager produksi. Sistem informasi yang dibuat adalah sistem informasi persediaan bahan baku kacang shanghai berbasis web dengan menggunakan database MySQL. Bahan baku disebut sebagai barang pada pembuatan rancangan sistem persediaan bahan baku ini.

\section{Analisis Sistem}

Analisis sistem bertujuan untuk memberikan gambaran tentang sistem informasi yang akan diteliti, yaitu mengenai basis data dan persediaan bahan baku kacang shanghai. Pengamatan langsung terhadap sistem informasi persediaan bahan baku pada UD. XY meliputi analisis input, analisis proses, dan analisis output. 


\section{Analisis Input}

Analisis input menganalisis segala sesuatu yang masuk ke dalam sistem dan selanjutnya menjadi bahan yang diproses. Data-data yang akan dijadikan sebagai input data ditentukan pada tahap ini. Data tersebut adalah data bahan baku, data stok bahan baku, data supplier, dan data pemakaian bahan baku.

\section{Analisis proses}

Tahap ini menganalisis bagian yang melakukan perubahan atau transformasi dari masukan menjadi keluaran yang lebih bernilai. Proses yang terdapat dalam sistem informasi persediaan bahan baku ini meliputiproses sejak bahan baku datang dari supplier dan pencatatan jumlah kedatangan bahan baku, proses pencatatan ketersediaan bahan baku digudang, bahan baku yang telah terpakai dan bahan yang tersisa, proses pembuatan laporan mengenai aliran persediaan bahan baku, serta dokumentasi.

Proses bahan baku masuk berisi form yang berguna untuk memasukkan data bahan baku yang masuk menuju gudang ke dalam database. Pengguna memasukkan data bahan baku yang masuk yaitu, tanggal, Identitas (ID) supplier, ID bahan baku, kuantitas bahan baku yang masuk serta tanggal expired. Sistem kemudian akan menampilkan total harga yang yang diperoleh dengan rumus:

$\begin{aligned} \text { Total harga }= & \text { harga per item bahan baku } * \text { kuantitas } \\ & \text { bahan baku masuk }\end{aligned}$

Proses bahan baku keluar berisi form yang berguna untuk memasukkan data bahan baku yang keluar gudang untuk proses produksi kacang shanghai ke dalam database. Pengguna mencari nama bahan baku yang akan dipakai kemudian memasukkan tanggal bahan baku keluar.Informasi mengenai jumlah bahan baku yang tersedia muncul setelah pengguna memilih nama bahan baku. Terdapat preview tabel bahan baku masuk yang berisi nama, kode, jumlah dan tanggal expiredbahan baku yang dapat digunakan sebagai pertimbangan untuk mengeluarkan barang sesuai dengan prinsip First Expired First Out (FEFO), yaitu barang dengan masa kadaluarsa paling dekat harus dipakai terlebih dahulu.

Jika pengguna mengeluarkan sejumlah bahan baku dari gudang sehingga menyisakan persediaan bahan baku dalam gudang tersebut kurang atau sama dengan batas stock yang telah ditentukan sebelumnya, maka akan keluar peringatan pada submenu proses bahan baku keluar yang menyatakan bahwa pengeluaran bahan baku melebihi batas stock aman yang penentuannya ditetapkan berdasarkan kebijakan perusahaan. Kuantitas stock akhir ditentukan dengan rumus:
Stock $=($ kuantitas bahan baku yang masuk + in hand inventory)

\section{- $\quad$ (kuantitas bahan baku keluar)}

\section{Analisis Output}

Tahap ini menganalisis hasil dari pemrosesan. Output dapat berupa suatu informasi, saran, cetakan laporan, dan sebagainya. Laporan yang dihasilkan pada persediaan barang ini adalah laporan terhadap manager produksi berupa hasil laporan yang keluar setelah sistem pemrosesan. Laporan tersebut kemudian dapat dicetak untuk dijadikan laporan saat diperlukan dan dapat disimpan dalam komputer sebagai arsip.

\section{Pengumpulan Data}

Jenis data dalam penelitian ini adalah data primer dan sekunder. Data primer merupakan data yang diperoleh secara langsung dari UD. XY, seperti jenis bahan baku kacang shanghai. Data sekunder merupakan data yang diperoleh bukan melalui pengukuran / pengamatan langsung, yaitu data-data yang diperoleh dari dokumen perusahaan, bukubuku literatur, artikel, dan jurnal yang terkait dengan penelitian yang dilakukan, seperti data kedatangan bahan baku, pemakaian bahan baku, data ketersediaan bahan baku dalam gudang, serta data mengenai supplier

Metode pengumpulan data yang digunakan dalam penelitian ini yaitu observasi, wawancara, dokumentasi, dan studi pustaka. Observasi dilakukan dengan cara pencatatan secara cermat dan sistematik. Wawancara dilakukan dengan tanya jawab secara langsung kepada operator / mandor dan bagian administrasi gudang yang merupakan calon pengguna sistem informasi. Dokumentasi dilakukan dengan mengumpulkan catatan-catatan tertulis, dokumen, maupun laporan-laporan yang berhubungan dengan data yang dibutuhkan dalam melakukan perancangan sistem informasi persediaan bahan baku. Studi pustaka dilakukan dengan mengkaji teori yang berhubungan dengan perancangan sistem informasi persediaan bahan baku.

\section{Pemodelan Sistem}

Pemodelan sistem dimulai dengan perancangan yang memberikan gambaran mengenai sistem informasi yang yang dibangun menggunakan konsep Object Oriented Programming (OOP). Menurut Paetau (2005), pengembangan sistem informasi akan lebih cepat dan efisien jika menggunakan OOP. Hal ini karena $O O P$ mendukung penggunaan kembali, yaitu aplikasi baru tidak harus selalu dikembangkan dari awal. Dukungan, pemeliharaan, dan pelayanan sistem informasi juga akan lebih mudah sehingga lebih murah.

Perancangan pada pembuatan sistem informasi ini menggunakan Unified Modeling 
Language (UML). versi 2.0 yang terdiri dari 13 teknik diagram. Menurut Dennis et al. (2012), UML versi 2.0 mendefinisikan 13 diagram $U M L$ yang dapat digunakan untuk memodelkan suatu sistem. Structure diagram pada perancangan sistem informasi persediaan bahan baku ini menggunakan class diagram, sedangkan behavior diagrams terdiri dari use case diagram, activity diagram, dan sequence diagram.

Metode pendekatan sistem yang digunakan dalam penelitian ini adalah prototyping. Prototyping merupakan metode pengembangan sistem menggunakan pendekatan untuk membuat suatu program dengan cepat dan bertahap sehingga segera dapat dievaluasi oleh pemakai. Tahapan perancangan menggunakan prototyping dapat dilihat pada Gambar 1.

\section{Identifikasi Kebutuhan Pengguna}

Kegiatan yang dilakukan pada tahap ini adalah menganalisis kebutuhan yang terdapat pada masalah yang ada. Identifikasi kebutuhan pengguna sistem informasi dilakukan dengan wawancara kepada pengguna terkait sistem informasi yang diinginkan. Identifikasi kebutuhan pemakai juga dilakukan dengan observasi secara langsung di UD. XY.

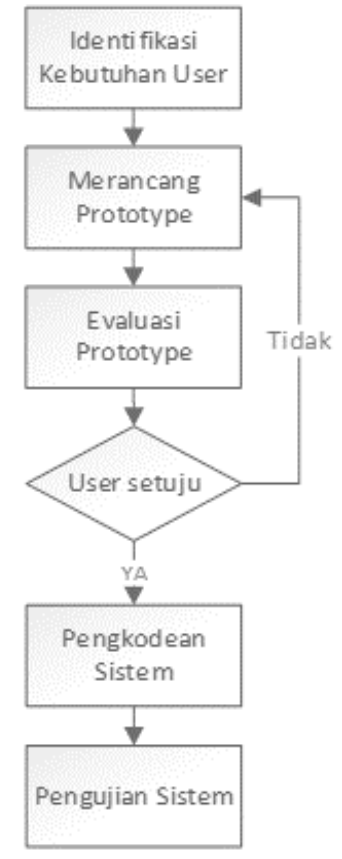

Gambar 1. Tahapan metode prototyping

\section{Perancangan Prototype}

Kegiatan yang dilakukan pada tahap ini adalah membuat model permasalahan yang ada. Perancangan dilakukan dengan menyususun kebutuhan yang digunakan ke dalam sebuah prototype awal sebagai gambaran sistem yang akan di bangun.

\section{Evaluasi Prototype}

Gambaran sistem yang akan dibangun dievaluasi pada tahap in dengan tujuan untuk mendapatkan saran dan masukan dari pengguna sistem informasi. Jika pada tahap ini masih ada revisi, maka perbaikan dan perancangan ulang prototype harus dilakukan. Apabila pengguna setuju, maka dapat dilanjutkan ke tahap pengkodean sistem.

\section{$\underline{\text { Pengkodean Sistem }}$}

Prototyping yang sudah disepakati kemudian diterjemahkan pada tahap ini ke dalam bahasa pemrograman PHP. Desain tampilan interface dibuat dengan HTML, CSS, dan Javascript serta bantuan framework Bootstrap, Code Igniter, dan menggunakan database MySQL. Desain user interface difokuskan pada interaksi yang terjadi antara pengguna dan sistem komputer yang mencakup metode input-output serta konversi data dan informasi antara form-form yang dapat dibaca manusia dan yang dapat dibaca komputer (Effendi et al., 2016).

\section{Pengujian Sistem}

Tahapan pengujian sistem dilakukan untuk mengetahui apakah sistem yang dirancang dapat berjalan sesuai dengan aturan yang berlaku serta memenuhi kebutuhan pengguna sesuai kondisi nyata. Pengujian dilakukan dengan cara:

1. Uji Verifikasi

Uji verifikasi digunakan untuk membuktikan bahwa sebuah algoritma berjalan dengan benar sesuai spesifikasi yang didefinisikan oleh pengembang sistem (Caughlin, 2000). Sistem informasi dinyatakan lulus uji verifikasi jika dapat dijalankan pada satu perangkat komputer, berjalan sesuai dengan aturan yang ada, dan tidak terdapat bug atau kecacatan

2. Uji Validasi

Uji validasi rancangan sistem informasi bertujuan untuk menguji apakah sistem telah memberikan informasi sesuai kebutuhan pengguna. Metode yang digunakan pada validasi adalah metode black boxtesting. Black box testing merupakan metode pengujian yang dilakukan hanya mengamati hasil eksekusi melalui data uji dan memeriksa fungsional dari sistem informasi. Uji coba black box berusaha untuk menemukan kesalahan dalam beberapa kategori diantaranya fungsi-fungsi yang salah atau hilang, kesalahan interface, kesalahan dalam struktur data atau akses database eksternal, kesalahan kinerja, serta kesalahan inisialisasi dan terminasi (Mustaqbal et al., 2015).

3. Uji Rancangan Sistem

Uji rancangan sistem bertujuan untuk mengetahui apakah sistem informasi yang dibuat merupakan alternatif yang lebih baik daripada sistem yang telah ada saat ini. Pengujian dilakukan dengan membandingkan sistem 
informasi yang sudah ada pada UD.XY dengan sistem informasi yang baru dibuat pada perancangan ini. Perbandingan sistem informasi dilakukan menggunakan analisis kerangka PIECES yang menguraikan kedalam enam fokus analisis, yaitu Performance, Information, Economy, Control, Efficiency, dan Service. Hasil dari analisis ini dapat menjelaskan keunggulan sistem baru dibandingkan dengan sistem yang lama (Afrina dan Ali, 2012).

\section{HASIL DAN PEMBAHASAN}

\section{Analisis Sistem}

Analisis sistem dimulai dengan identifikasi informasi yang dibutuhkan dalam perancangan sistem informasi berdasarkan hasil observasi lapangan serta wawancara dengan calon pengguna, yaitu bagian administrasi gudang. Proses alur penerimaan bahan baku pada UD. XY dimulai pada saat bahan baku dari pemasok tiba di pabrik. Pemasok bahan baku datang dengan membawa surat jalan yang kemudian diserahkan kepada petugas pabrik untuk melakukan pemeriksaan bahan baku mengenai kelengkapan fisik dan kesesuaian dengan surat jalan. Bahan baku kemudian dikirimkan ke masing-masing gudang penyimpanan untuk ditata. Mandor masing-masing gudang mencatat persediaan gudang saat ini pada kartu stok yang berisi tanggal bahan masuk gudang, aliran keluar dan masuk bahan baku, serta sisa bahan yang di gudang. Tahap berikutnya adalah pembuatan laporan mengenai aliran bahan baku serta ketersediaan bahan baku dalam gudang. Sistem informasi yang dibuat ini juga dirancang untuk kebutuhan pengguna jika UD. XY akan menggunakan sistem informasi untuk bagian administrasi gudang, operator / mandor gudang, dan manager produksi.

Operator / mandor gudang pada sistem ini dapat login dan masuk ke halaman data persediaan bahan baku serta melakukan input data persediaan, yaitu jumlah bahan baku yang masuk, tersedia, dan keluar gudang. Manager produksi dapat melihat dan mencetak laporan persediaan bahan baku. Bagian administrasi gudang memiliki peran dalam mengelola sistem informasi pergudangan, termasuk melakukan login ke dalam sistem, memasukkan data bahan baku, mengatur batas safety stock bahan baku, input data persediaan bahan baku yang masuk dan terpakai di gudang, serta melihat hasil laporan untuk dicetak menjadi laporan bahan baku masuk, bahan baku keluar, dan persediaan bahan baku. Daftar informasi yang dibutuhkan pengguna dapat dilihat pada Tabel 1.

\section{Pemodelan Sistem}

Setelah memperoleh data dari hasil observasi dan analisis mengenai kebutuhan pengguna, pemodelan sistem dengan pendekatan prototyping dibuat sebagai gambaran sistem informasi yang akan dibangun. Prototype didefinisikan sebagai satu versi dari sebuah sistem potensial yang memberikan ide bagi para pengembang dan calon pengguna, yaitu bagaimana sistem akan berfungsi dalam bentuk yang telah selesai (Veronica dan Darnita, 2015). Beberapa contoh Prototype yang dibangun dapat dilihat pada Gambar 2.

Prototype halaman awal login merupakan rancangan halaman tempat pengguna sistem memasukkan username dan password untuk masuk ke dalam sistem informasi. Prototype menu master adalah rancangan menu halaman yang di dalamnya terdapat informasi mengenai stok bahan baku serta data atribut bahan baku dan supplier. Prototype master data barang digunakan untuk memasukkan atribut bahan baku. Prototype proses barang masuk digunakan untuk memasukkan data bahan baku yang masuk ke dalam persediaan dalam gudang. Prototype laporan barang masuk merupakan rancangan output laporan mengenai bahan baku yang masuk dalam gudang.

Tabel 1. Daftar Kebutuhan Informasi Pengguna

\begin{tabular}{clll}
\hline No & \multicolumn{1}{c}{$\begin{array}{c}\text { Kebutuhan } \\
\text { Informasi }\end{array}$} & \multicolumn{1}{c}{ Rincian } & \multicolumn{1}{c}{ Manfaat } \\
\hline 1 & $\begin{array}{l}\text { Bahan baku kacang } \\
\text { shanghai } \\
\text { Supplier }\end{array}$ & $\begin{array}{l}\text { Kode barang, nama, harga, } \\
\text { satuan } \\
\text { ID supplier, nama, alamat, } \\
\text { telepon }\end{array}$ & $\begin{array}{l}\text { Membantu dalam pengawasan persedian } \\
\text { ID transaksi, tanggal, kode } \\
\text { manajer dalam pembelian bahan baku selanjutnya }\end{array}$ \\
3 & Bahan baku masuk & \\
4 & $\begin{array}{l}\text { Ketersediaan bahan } \\
\text { baku }\end{array}$ & $\begin{array}{l}\text { Stok, jumlah stok } \\
\text { Bahan baku keluar }\end{array}$ & $\begin{array}{l}\text { Kode barang, tanggal, } \\
\text { jumlah stok }\end{array}$ \\
6 & $\begin{array}{l}\text { Bahan baku } \\
\text { stockout }\end{array}$ & Stok aman, stok warning & \\
\hline
\end{tabular}




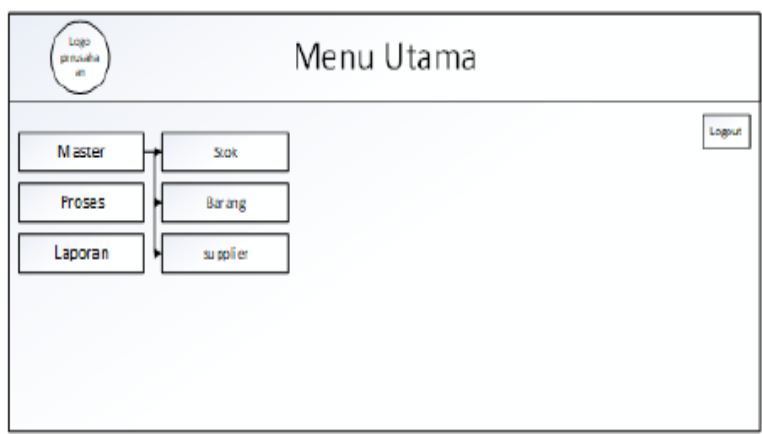

(a) Prototype menu master

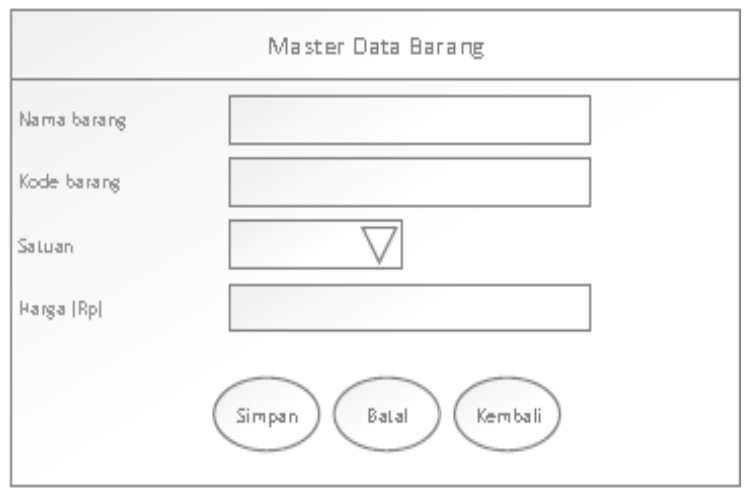

(c) Prototype master data bahan baku

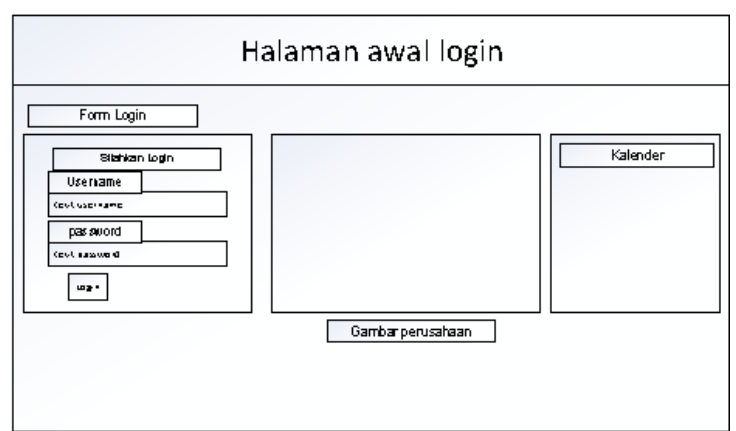

(b) Prototype halaman awal login

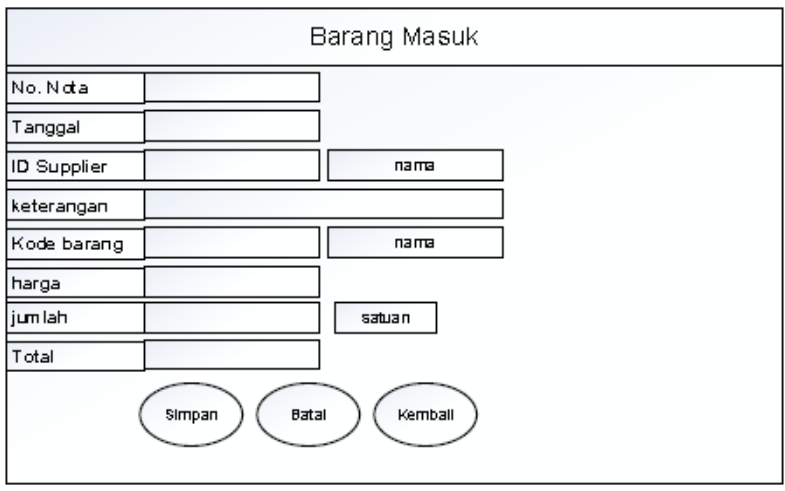

(d) Prototype proses bahan baku masuk

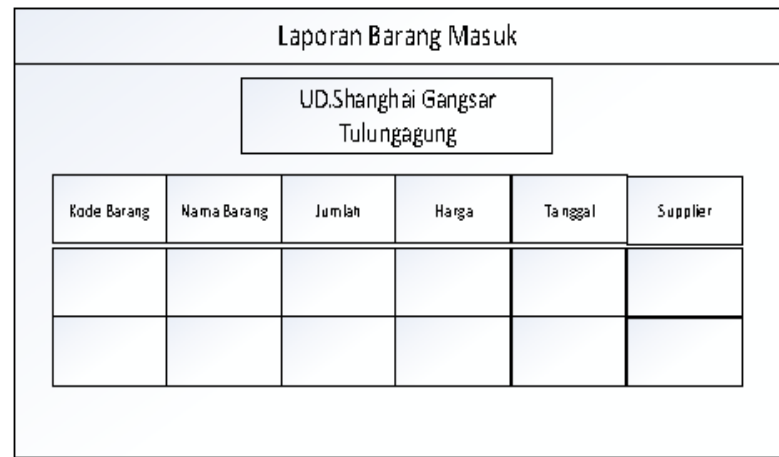

(e) Prototype laporan bahan baku masuk

Gambar 2. Rancangan prototype sistem informasi persediaan bahan baku

Perancangan Unified Modeling Language (UML)

Diagram pada UML versi 2.0 dalamperancangan sistem informasi ini hanya digunakan sesuai kebutuhan analisis dan perancangan sistem informasi yang akan dibuat (Haviluddin, 2011). Struktur diagram yang digunakan yaitu: use case, class diagram, activity diagram, dan sequence diagram yang dapat dilihat pada Gambar 3.

Use case diagram menyajikan interaksi antara use case dan aktor. Diagram use case tersebut mempunyai tiga aktor, yaitu bagian administrasi gudang, operator/mandor gudang, dan manager produksi. Class diagram menggambarkan struktur objek sistem yang membuat objek-objek yang terdapat dalam sistem beserta hubungan antar objek. Activity diagram dimulai pada saat pengguna melakukan login pada sistem dengan memasukkan username dan password yang kemudian divalidasi oleh sistem. Jika valid, maka pengguna akan masuk ke halaman utama. Administrasi sistem sebaga level tertinggi dari sistem informasi dapat melakukan seluruh kegiatan dalam sistem yang meliputi input data master bahan baku, input data persediaan bahan baku, serta melihat dan mencetak laporan. Proses sequence diagram login dimulai ketika pengguna menggunakan form login untuk masuk ke dalam sistem informasi. Username dan password kemudian divalidasi untuk mengecek kesesuaian dengan data pada sistem. Sistem akan mengecek level sesuai username dan password sehingga sistem dapat menampilkan halaman utama sesuai dengan kebutuhan pengguna. 


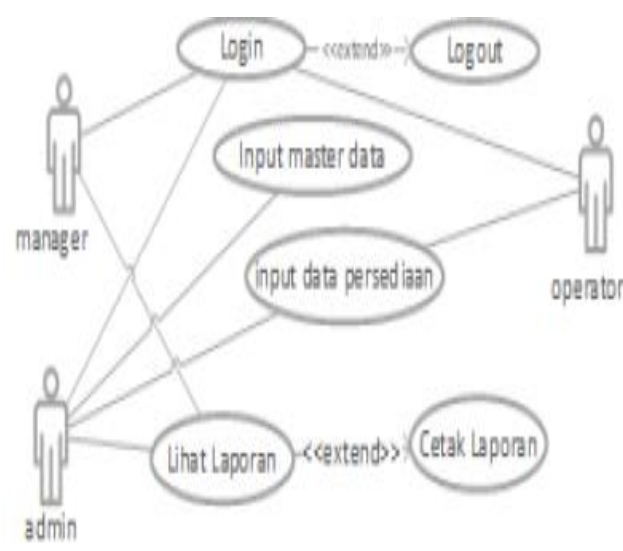

(a) Use case diagram sistem informasi

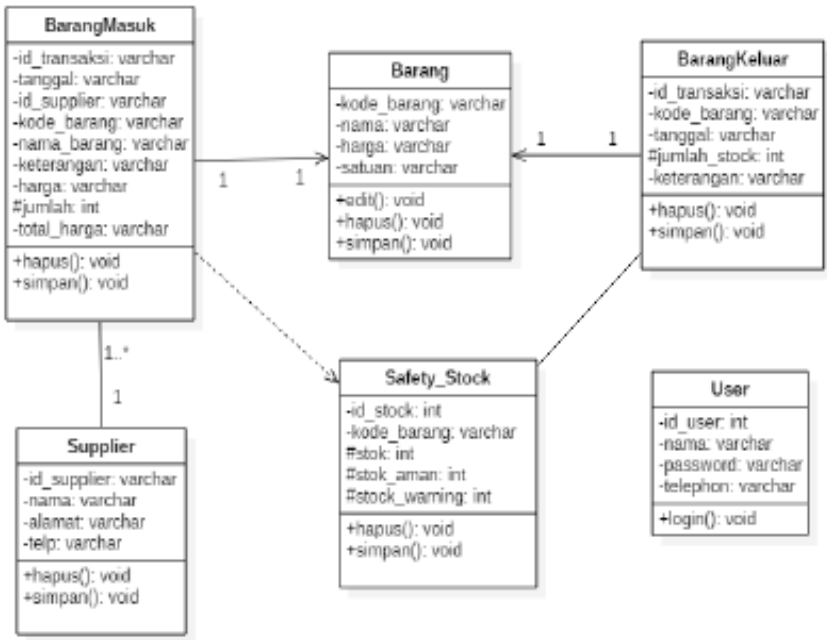

(b) Class diagram sistem informasi

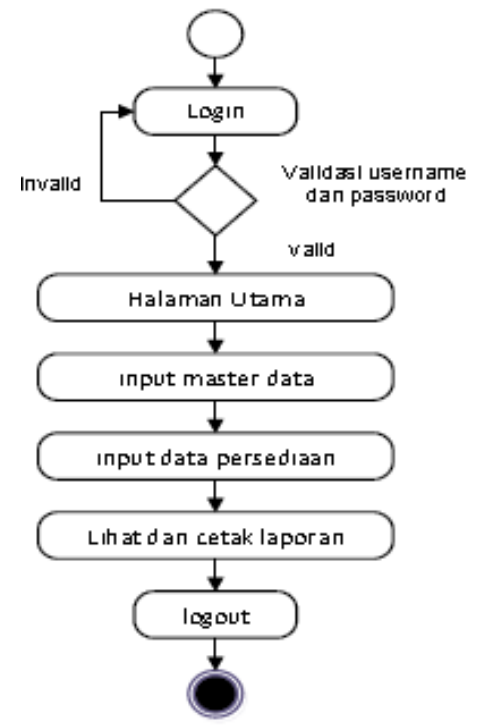

(c) Activity diagram sistem informasi

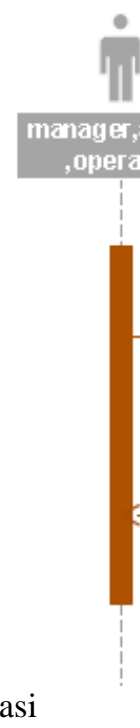

(d) Sequence diagram sistem informasi Login Administrasi Sistem

Gambar 3. Diagram UML sistem informasi persediaan bahan baku

Use case diagram menyajikan interaksi antara use case dan aktor. Diagram use case tersebut mempunyai tiga aktor, yaitu bagian administrasi gudang, operator/mandor gudang, dan manager produksi. Class diagram menggambarkan struktur objek sistem yang membuat objek-objek yang terdapat dalam sistem beserta hubungan antar objek. Activity diagram dimulai pada saat pengguna melakukan login pada sistem dengan memasukkan username dan password yang kemudian divalidasi oleh sistem. Jika valid, maka pengguna akan masuk ke halaman utama. Administrasi sistem sebaga level tertinggi dari sistem informasi dapat melakukan seluruh kegiatan dalam sistem yang meliputi input data master bahan baku, input data persediaan bahan baku, serta melihat dan mencetak laporan. Proses sequence diagram login dimulai ketika pengguna menggunakan form login untuk masuk ke dalam sistem informasi. Username dan password kemudian divalidasi untuk mengecek kesesuaian dengan data pada sistem. Sistem akan mengecek level sesuai username dan password sehingga sistem dapat menampilkan halaman utama sesuai dengan kebutuhan pengguna.

\section{Hasil Pemodelan Sistem Informasi}

Hasilrancangan sistem diimplementasikan ke dalam sebuah sistem informasi yang diakses melalui komputer. Tampilan pertama adalah halaman awal yang berisikan form login bagi pengguna sistem informasi persediaan bahan baku, yaitu bagian administrasi gudang, operator / mandor gudang, dan manager produksi. Halaman awal ini ditampilkan saat pengguna pertama kali mengakses sistem informasi. Tampilan halaman awal dapat dilihat pada Gambar 4.

Setelah pengguna berhasil melakukan login, maka pengguna masuk ke dalam tampilan halaman 
utama atau beranda. Halaman utama pada sistem persediaan bahan baku berisi menu utama, yaitu menu master, menu proses, dan menu laporan. Tampilan halaman utama dapat dilihat pada Gambar 5.

Menu master memiliki lima submenu yaitu: master barang, tambah barang, set safety stock, tambah supplier dan informasi supplier. Contoh tampilan pada menu master dapat dilihat sebagai berikut:

\section{Master barang}

Informasi mengenai daftar bahan baku yang digunakan untuk proses produksi kacang shanghai terdapat pada master barang. Data bahan baku yang disajikan meliputi kode barang, nama, harga, dan satuan. Tampilan master barang dapat dilihat pada Gambar 6.

\section{Submenu tambah barang}

Submenu tambah barang berisi form yang berfungsi untuk menambahkan data bahan baku kacang shanghai. Pengguna memasukkan data bahan baku yang meliputi nama, satuan, dan harga kemudian klik tombol simpan untukmenyimpan data bahan baku ke dalam database.Form tambah barang dapat dilihat pada Gambar 7.

\section{Submenu set safety stock}

Submenu set safety stock berfungsi untuk menentukan batas stok aman dan stok warning suatu bahan baku. Pengguna dapat mengatur stok aman dan stok warning sesuai kebijakan pabrik. Form set safety stock dapat dilihat pada Gambar 8 .

Menu Proses adalah menu yang berisikan proses bahan baku yang masuk dan keluar dari gudang bahan baku. Menu proses terdiri dari dua proses, yaitu proses barang masuk dan proses barang keluar seperti yang ditunjukkan pada Gambar 9.

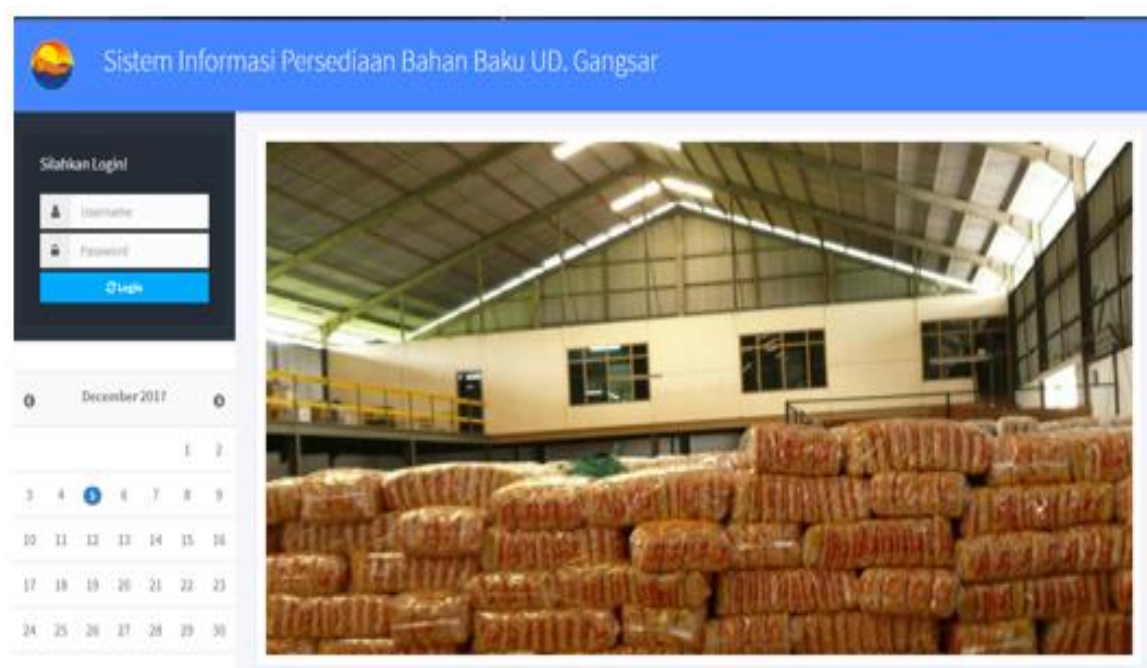

Gambar 4. Tampilan halaman awal

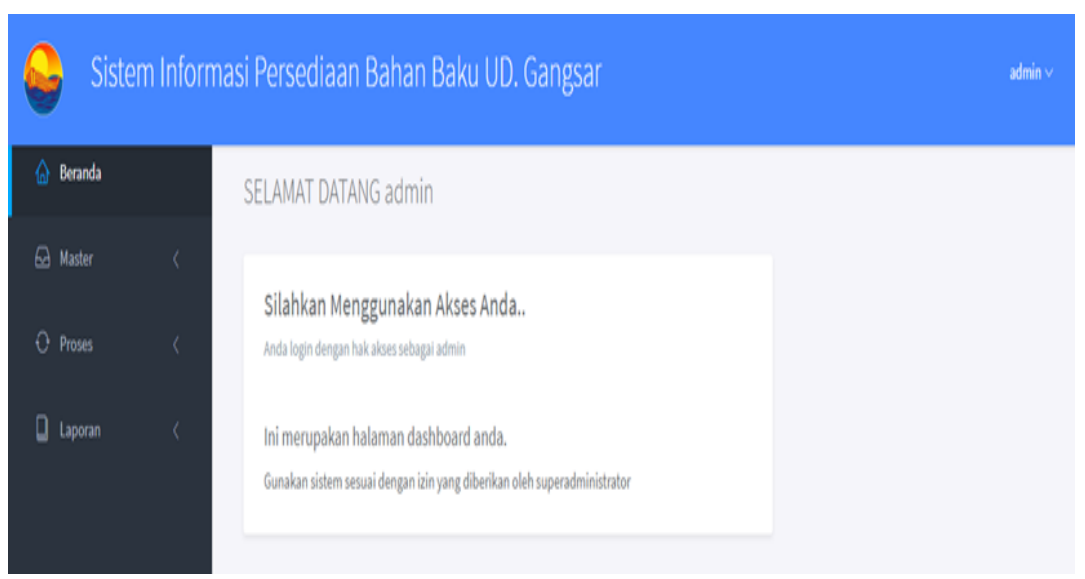

Gambar 5. Tampilan halaman utama 


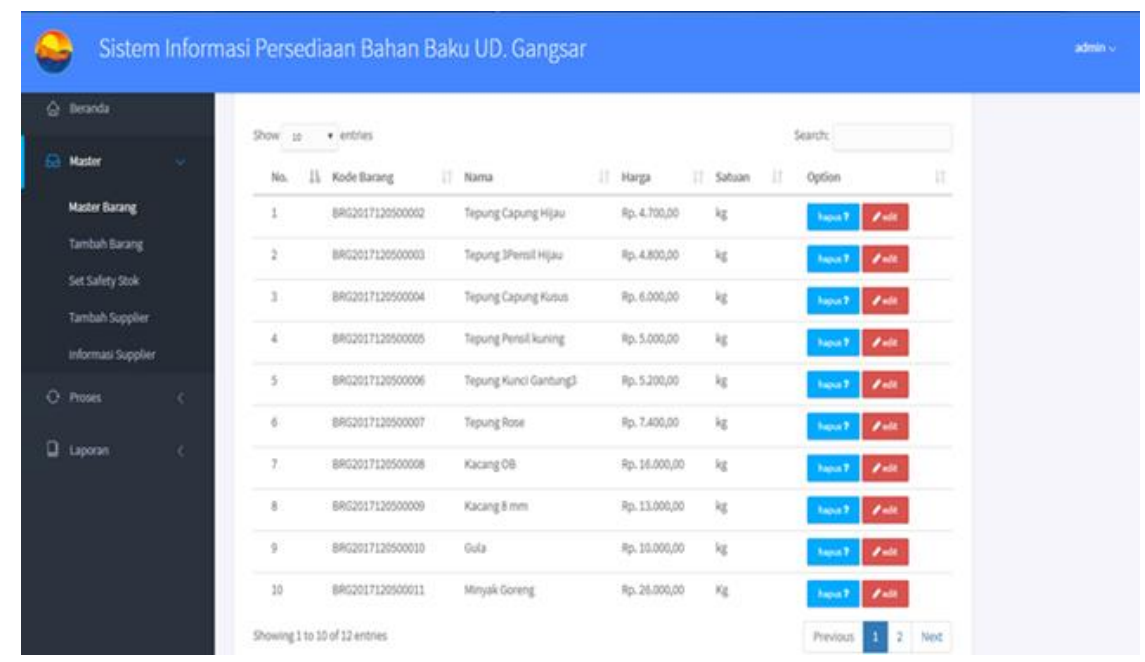

Gambar 6.Tampilan halaman master barang

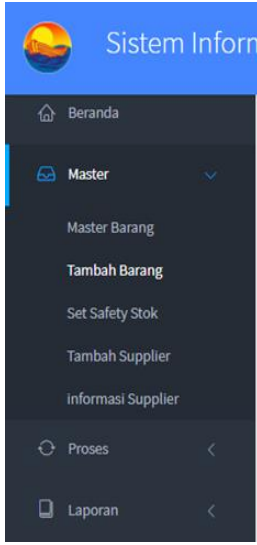

Gambar 7. Tampilan form tambah barang
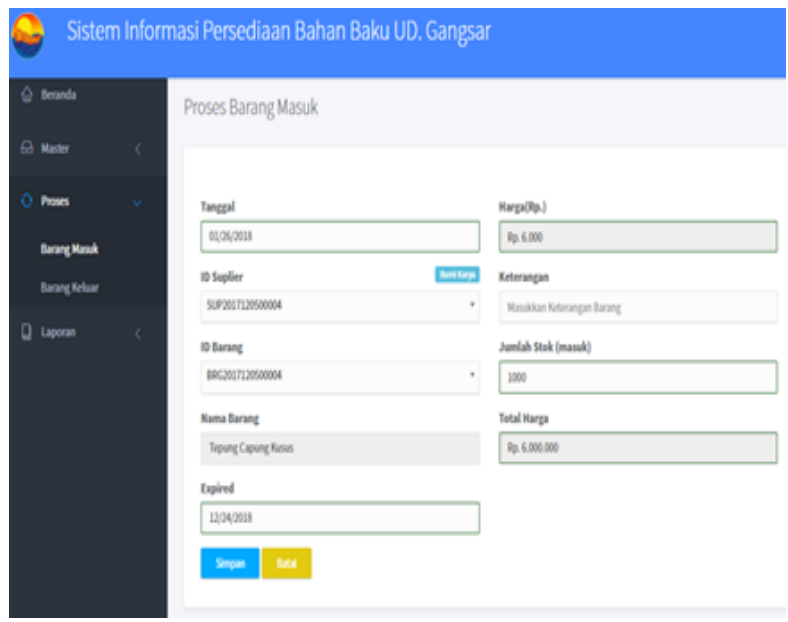

(a) Tampilan form proses barang masuk

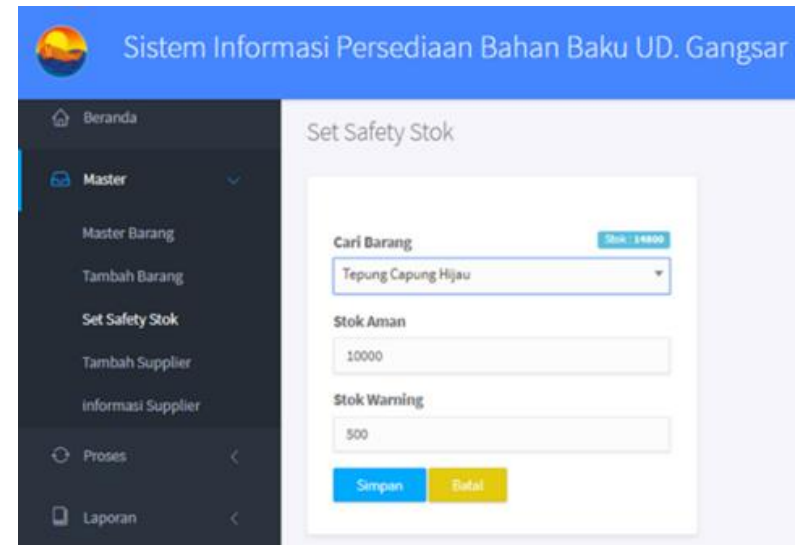

Gambar 8. Tampilan set safety stock

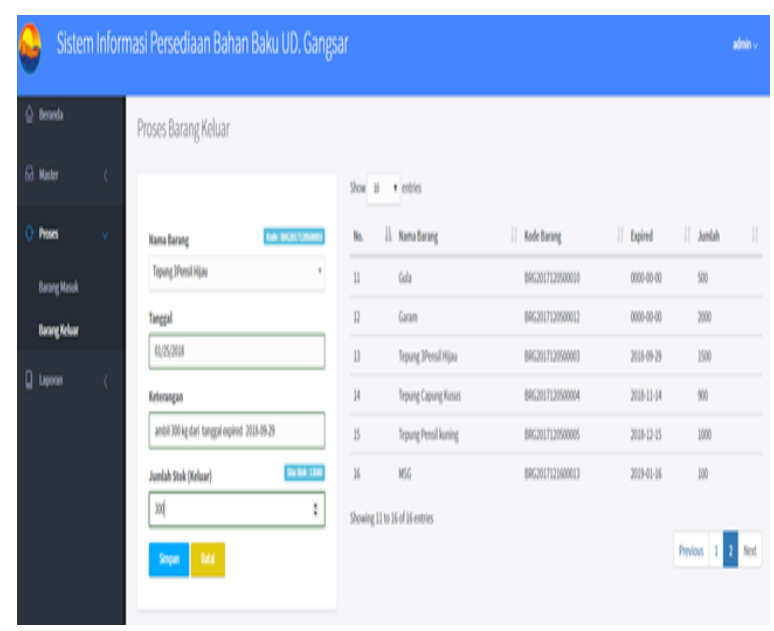

(b) Tampilan form proses barang keluar

Gambar 9.Tampilan menu proses 
Proses barang keluar berisi form yang berguna untuk memasukkan data bahan baku yang keluar gudang untuk proses produksi kacang shanghai ke dalam database. Pengguna mencari nama bahan baku yang akan dipakai dalam kolom nama barang yang jika di-klik akan muncul dropdown daftar nama bahan baku. Kolom tanggal untuk memasukkan tanggal bahan baku keluar, dengan format bulan, tanggal, dan tahun. Keterangan bersifat opsional dapat diisi mengenai penggunaan bahan baku tersebut. Pada bagian atas kolom jumlah stok keluar, terdapat informasi mengenai jumlah bahan baku yang tersedia.
Menu laporan berisi laporan mengenai laporan barang masuk, laporan barang keluar, dan laporan stock barang. Tampilan menu laporan dapat dilihat pada Gambar 10. Informasi mengenai nomer nota, kode barang, nama barang, nama supplier, harga, jumlah stok yang masuk, total harga, tanggal barang masuk dan tanggal expired barang terdapat pada laporan barang masuk. Laporan barang keluar berisi informasi mengenai bahan baku yang keluar yang meliputi nomer nota, kode barang, nama barang, jumlah stok yang keluar, keterangan, dan tanggal barang tersebut keluar dari gudang. Tombol print berfungsi untuk mencetak laporan.

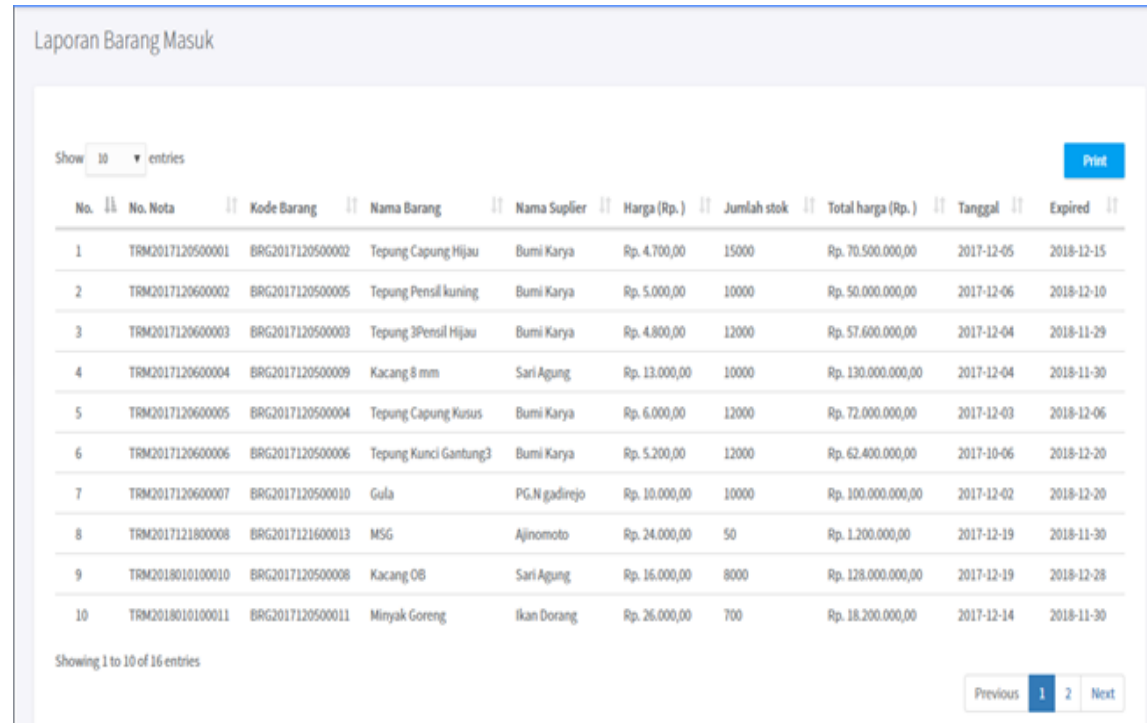

(a) Laporan barang masuk

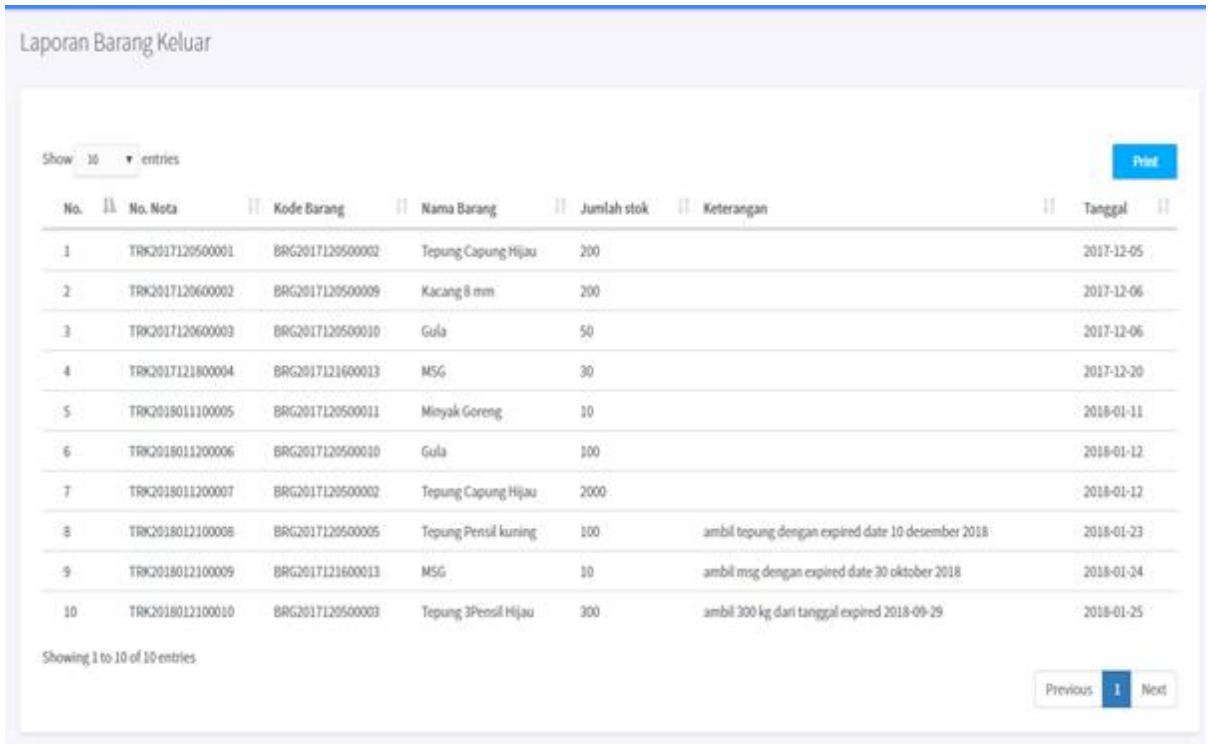

(b) Laporan barang keluar

Gambar 10. Tampilan menu laporan 


\section{Pengujian Sistem}

Tahapan terakhir dalam perancangan sistem informasi adalah melakukan pengujian sistem. Pengujian bertujuan untuk mengetahui apakah rancangan sistem informasi yang dibuat telah sesuai dengan yang diinginkan dengan cara verifikasi dan validasi, serta uji rancangan sistem.

\section{Verifikasi}

Proses verifikasi bertujuan untuk mengevaluasi apakah proses sudah berjalan sesuai dengan rancangan yang telah dibuat. Proses verifikasi yang telah dilakukan antara lain sudah terdapat text box yang berguna untuk memasukkan dan mengedit data pada form yang tersedia pada sistem informasi persediaan bahan baku. Form telah dapat terhubung dengan tabel pada database, misal: form input bahan baku terhubung dengan tabel barang pada database.

Hal lain yang dilakukan pada uji verfikasi adalah: konfirmasi username dan password yang telah dimasukkan oleh pengguna dan mengarahkan pengguna pada halaman utama, menghapus data rocord bahan baku kacang shanghai pada database, menyimpan input data ke dalam tabel pada database, menghapus atau membatalkan input data pada form yang telah diisi, serta mencetak laporan data persediaan barang masuk, barang keluar dan safety stock. Pengecekan bahwa logout berfungsi untuk keluar dari sistem informasi dan mengarahkan pada halaman awal login juga dilakukan pada uji verifikasi ini.

\section{Validasi}

Proses validasi berfungsi untuk menguji apakah sistem telah memberikan informasi sesuai kebutuhan pengguna. Pengujian validasi menggunakan metode black box testing. Hasil dari pengujian yang dilakukan pada sistem informasi tersebut adalah semua tampilan menu dan submenu yang terdapat pada halaman utama dapat diakses oleh bagian administrasi gudang, operator / mandor gudang, dan manager produksi secara baik dan berfungsi dengan lancar yang meliputi tombol, textfield dan koneksi database, serta memberikan informasi sesuai kebutuhan pengguna.

\section{Uji Rancangan Sistem}

Uji rancangan sistem bertujuan untuk mengetahui keunggulan sistem baru dibandingkan sistem lama. Perbandingan sistem lama dan sistem baru berdasarkan analisis Performance, Information, Economy, Control, Efficiency, dan Services (PIECES). Hasil perbandingan antara sistem informasi lama dan sistem informasi baru mengenai persediaan bahan baku tersebut menunjukkan bahwa sistem informasi persediaan bahan baku yang telah dirancang lebih unggul dan dapat digunakan untuk meningkatkan kinerja dari sistem informasi persediaan bahan baku di UD. XY pada saat ini.
Keunggulan sistem informasi hasil rancangan ini adalah lebih efektif karena sudah terkomputerisasi dan dapat terhubung dalam jaringan lokal perusahaan sehingga mempercepat arus informasi serta proses pembuatan laporan, data persediaan bahan baku tersimpan secara sistematis dalam database komputer sehingga perusahaan dapat menerapkan paperless system dalam rangka penghematan biaya dan pelestarian lingkungan, serta kesalahan dalam mengelola data persediaan pun dapat diminimalkan. Hasil uji coba menunjukkan bahwa hasil laporan persediaan bahan baku menggunakan sistem informasi ini sama dengan kondisi nyata persediaan bahan baku di UD. XY. Bagian administrasi gudang sebelumnya dapat melaporkan kondisi persediaan bahan baku sehari setelah proses produksi dilakukan, sedangkan penggunaan sistem informasi ini dapat membantu bagian administrasi gudang pada setiap akhir hari kerja.

\section{Implikasi Manajerial}

Hasil analisis menunjukkan bahwa Sistem informasi persediaan bahan baku dapat diterapkan pada perusahaan UD. XY untuk meningkatkan efektivitas pada proses pencatatan dan pelaporan data bahan baku kacang shanghai. Rancangan sistem informasi ini tidak terlepas dari beberapa keterbatasan pada penerapannya. Keterbatasan dan kelemahan dari penelitian ini antara lain adalah sebagian data bahan baku bersifat rahasia sehingga menghambat dalam proses perancangan sistem informasi. UD. XY juga masih memiliki keterbatasan tenaga kerja ahli serta sarana dalam hal teknologi informasi sehingga dapat menghambat pada penerapan sistem informasi yang terkomputerisasi.

Untuk mencapai kondisi yang ideal dalam implementasi Sistem Informasi Persediaan Bahan Baku pada UD. XY, maka pihak manajemen hendaknya mempertimbangkan peningkatan keahlian mengenai teknologi informasi pada tenaga kerja yang berperan langsung pada sistem informasi, perekrutan tenaga kerja baru yang memiliki keahlian dalam bidang sistem informai, sertapengadaan sarana dan prasarana untuk menunjang implementasi sistem informasi persediaan bahan baku.

Hasil penelitian ini dapat ditindaklanjuti dengan mengusulkan rekomendasi penyempurnaan model sistem informasi pada UD. XY yang bertujuan agar dalam pengembangan sistem informasi dapat dirancang sistem informasi yang lebih baik. Rekomendasi pengembangan sistem informasi persediaan bahan baku pada UD. XY, yaitu:

1. Integrasi Sistem Informasi

Pengintegrasian sistem informasi merupakan salah satu konsep kunci dalam sistem informasi manajemen. Aliran informasi di antara sistem sangat bermanfaat bila output dari suatu sistem 
menjadi input bagi sistem lainnya. Informasi persediaan dari gudang bahan baku dibutuhkan pada bagian produksi di UD. XY untuk mengetahui informasi persediaan bahan baku yang akan dipakai dalam proses prduksi kacang shanghai. Sistem yang mengatur aliran bahan baku dari gudang ke bagian produksi dapat dieksekusi secara real time sehingga sistem akan secara real time mengurangi jumlah bahan baku sebanyak bahan baku yang dikeluarkan dari gudang. Hal ini dilakukan karena tujuan utama dari sistem informasi adalah memberikan informasi yang benar dan akurat pada saat yang tepat.

2. Web Hosting

Sistem informasi persediaan bahan baku yang dirancang saat ini masih berjalan menggunakan jaringan lokal atau Local Area Network (LAN). Hal ini menyebabkan sistem hanya dapat diakses oleh pengguna selama pengguna tersebut berada pada area yang masih terjangkau oleh jaringan wifi perusahaan. Web hosting merupakan cara untuk mengatasi hal-hal tersebut. Web hosting adalah penyewaan tempat untuk menampung data-data yang diperlukan oleh sebuah website sehingga dapat diakses melalui internet.

3. Warehouse Management System (WMS)

WMS adalah sistem yang membantu perusahaan terkait dalam pengelolaan pergerakan barang dari atau ke dalam gudang. UD. XY menggunakan metode First Expired First Out (FEFO) pada manajemen pergudangan, yaitubarang dengan masa kadaluarsa paling dekat adalah barang yang harus dipakai terlebih dahulu tanpa memperhitungkan apakah barang tersebut datang lebih dulu atau terakhir. Sistem informasi yang dirancang saat ini mampu untuk menampilkan masa kadaluarsa barang sehingga dapat digunakan untuk mempertimbangkan dalam mengeluarkan barang menurut kadaluarsa.

\section{KESIMPULAN DAAN SARAN}

Rancangan sistem informasi persediaan bahan baku dilakukan menggunakan pendekatan metode prototyping dengan konsep Object Oriented Programming $(O O P)$ menggunakan $U M L$ versi 2.0. Informasi yang dihasilkan adalah informasi mengenai daftar bahan baku, pasokan bahan baku, penggunaan bahan baku, serta ketersediaan bahan baku dalam gudang. Sistem informasi dapat mengelola data input persediaan bahan baku menjadi output laporan persediaan. Pengujian sistem informasi secara verifikasi dan validasi menggunakan metode black box serta uji rancangan sistem menunjukkan bahwa sistem telah berjalan dengan baik dan dapat berjalan sesuai yang diharapan.

\section{DAFTAR PUSTAKA}

Afrina M dan Ibrahim A. 2012. Pengembangan model sistem informasi perpustakaan dengan teknologi informasi berbasis wireless application protocol (WAP) pada Universitas Sriwijaya. Jurnal Sistem Informasi. 4(1): 425-436.

Aristyanto RA. 2013. Perancangan Sistem Informasi Pengendalian Intern Persediaan Barang Pada CV. Prima Group Semarang. Information Technology and Telematics. Universitas Stikubank. Semarang.

Alter S. 2008. Defining Information Systems as Work Systems: Implications for the IS Field. European Journal of Information Systems.17(5):448-469.

Caughlin D. 2000. An integrated approach to verification, validation, and accredition of models and simulations. Proceedings of The $32^{\text {nd }}$ Conference on Winter Simulation. Orlando, Florida.

Cantwell M. 2014. Estimates of Shelf-life of Raw Nuts Held at Different Temperatures. Postharvest Center. University of California.

Dennis A, Wixom BH, dan Tegarden D. 2012. System Analysis and Design with UML version 2.0: An Object Oriented Approach. $4^{\text {th }}$ Edition. John Wiley \& Sons, Inc.

Effendi M, Cahyono E, dan Effendi U. 2016. Perancangan sistem informasi efektivitas dan efisiensi peralatan berbasis website (Studi Kasus di PT Kediri Matahari Corn Mills, Kediri). Industria: Jurnal Teknologi dan Manajemen Agroindustri. 5(3):159168.

Haviluddin. 2011. Memahami penggunaan UML (Unified Modeling Language). Jurnal Ilmiah Ilmu Komputer. 6(1):1-16.

Kelton WD, Sadowski RP, dan Zupick NB. 2009. Simulation with Arena. $5^{\text {th }}$ Edition. Mc Graw Hill.

Mustaqbal MS, Firdaus RF, dan Rahmadi H. 2015. Pengujian aplikasi menggunakan black box testing boundary value analysis (Studi Kasus: Aplikasi Prediksi Kelulusan SNMPTN). Jurnal Ilmiah Teknologi Informasi Terapan. 1(3):31-36.

Paetau P. 2005. On The Benefits and Problems of The Object Oriented Paradigm Including Finnish Study. Swedish School of Economics and Business Administration.

Prusak AM, Schlegel-Zawadzka M, Boulay A, Rowe G. 2014. Characteristics of the peanut chain in europe - implications for peanut allergy. Acta Scientiarum Polonorum Technologia Alimentaria. 13(3):321-333. 
Ramadhan TS. 2008. Perancangan Sistem Informasi Persediaan Barang Berbasis WEB pada Program Non Reguler Fakultas Sain dan Teknologi UIN Syarif Hidayatullah Jakarta. Fakultas Sains dan Teknologi. UIN Syarif Hidayatullah. Jakarta.

Ravinchandra KAL, Abdulla R, dan Thang KF. 2016. Smart stock management control. International Journal of Applied Engineering Research. 11(1):492-500.
Veronika NDM dan Darnita, Y. 2015. Rancang bangun aplikasi tes TOEFL menggunakan algoritma Quick Sort berbasis komputer. Jurnal Pseudocode. 2(2):89-97. 